\title{
Hederella carbonaria Condra \& Elias, 1944 from the Roadian (middle Permian) of Mexico
}

\author{
Sergio González-Mora, Patrick N. Wyse Jackson, Miguel A. Torres-Martínez, \\ Blanca E. Buitrón-Sánchez, Ricardo Barragán \& Francisco Sour-Tovar
}

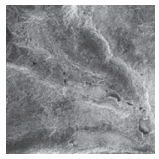

\begin{abstract}
Permian sclerobionts of brachiopods present in outcrops of clayey or silty limestones of the Paso Hondo Formation, in southern Mexico, include representatives of the enigmatic group Hederelloidea. This group, with uncertain affinities, has in the past generally been considered to be related to the Phylum Bryozoa but which, given its prismatic ultrastructure and larger size, is currently considered as an independent group of lophophorates. As with most sclerobiont faunas, the fossil record of hederelloids is abundant from the Silurian to Devonian, but they are very scarce in the Upper Paleozoic where they are restricted to subtropical paleolatitudes of moderate depth, calcareous shale or clay limestone facies. In particular, the genus Hederella has only been reported from the Carboniferous of North America and the United Kingdom and from the Permian (Sakmarian) of Siberia. The presence of hederelloids in the Paso Hondo Formation, which crops out in the State of Chiapas, on the border of Mexico and Guatemala, constitutes the first record of this group for Mexico, the youngest at a global level, and extends the temporal distribution of the Order Hederelloidea to the Roadian. The hederelloids present in the Paso Hondo Formation are attached to shells of rhynchonellid and athyridid brachiopods and associated with other sclerobionts, such as bryozoans of the orders Trepostomata and Cystoporata. - Key words: Hederelloidea, Permian, Brachiopods, Roadian, Sclerobionts, Chiapas, Mexico.
\end{abstract}

GonzÁlez-Mora, S., Wyse Jackson, P.N., Torres-Martínez, M.A., Buitrón-SÁnchez, B.E., Barragán, R. \& SourTovar, F. 2018. Hederella carbonaria Condra \& Elias, 1944 from the Roadian (middle Permian) of Mexico. Bulletin of Geosciences 93(4), 457-461 (4 figures, 1 table). Czech Geological Survey, Prague. ISSN 1214-1119. Manuscript received June 15, 2018; accepted in revised form September 20, 2018; published online October 17, 2018; issued December 20, 2018.

\begin{abstract}
Sergio González-Mora, Posgrado en Ciencias Biológicas, Universidad Nacional Autónoma de México, Ciudad Universitaria, 04510 Ciudad de México, México; gioser@ciencias.unam.mx・Patrick N. Wyse Jackson, Department of Geology, Trinity College, Dublin 2, Ireland • Miguel A. Torres-Martínez, Blanca E. Buitrón-Sánchez \& Ricardo Barragán, Departamento de Paleontología, Instituto de Geología, Universidad Nacional Autónoma de México, Ciudad Universitaria, 04510 Ciudad de México, México • Francisco Sour-Tovar, Museo de Paleontología, Departamento de Biología Evolutiva, Facultad de Ciencias, Universidad Nacional Autónoma de México, Ciudad Universitaria, 04510 Ciudad de México, México
\end{abstract}

The fossil record of sclerobionts is important for understanding the marine communities of the past. These fossils are usually well preserved and normally found in association with other organisms (Taylor \& Wilson 2003). Hederelloids are a group of extinct organisms with branched colonies, which occupied a wide variety of hard substrates, typically found as sclerobionts of brachiopods (Schneider 2008), bryozoans and corals (Taylor \& Wilson 2008). The geological record of the hederelloids dates from the Silurian; they reach their greatest abundance and diversity in the Devonian (Schneider 2013), and become extinct in the Permian. The Order Hederelloidea has been little studied in only a few major taxonomic works (Bassler 1939, Solle 1952, Kiepura 1973, Bancroft 1986, Taylor \& Wilson 2008). Their taxonomic affinities have been discussed by several authors (Brood 1973, 1975; Dzik 1981; Taylor \& Wilson 2008). Affinities have been suggested with cyclostomes bryozoans, phylactolaemate bryozoans and auloporid corals. However, the observations made by Taylor and Wilson (2008) differ from previous ones, and report that the hederelloids exhibit microprismatic calcite in the microstructure of the walls of their tubes that differs from the lamellar one found in Paleozoic bryozoans and auloporid corals. Given the pattern of branching, size, colonial habit and characteristics of its protozoecium, hederelloids have been considered to be related to phoronids (Taylor \& Wilson 2008). Currently five genera of hederelloids are recognized: Hederella Hall, Hederopsis Bassler, Herdonia Hall, Reptaria Rollé and Diversipora Kiepura. 
The genus Hederella Hall presents the largest number of species and the greatest temporal distribution (SilurianPermian) within the order. Hederella is abundant in the Devonian rocks but Late Paleozoic records of Hederella are rare (e.g., Girty in Gilluly 1932, Bassler 1939, Condra \& Elias 1944, Dunham \& Stubblefield 1944, Bancroft 1986, Lisitsyn 1998). Three species have been described from Carboniferous; one of them is Hederella carbonaria Condra \& Elias 1944 reported in the upper Carboniferous of Oklahoma and Utah (Condra \& Elias 1944) and the lower Carboniferous of Great Britain (Bancroft 1986). A possible Hederella specimen from the upper Carboniferous of Svalbard, Norway is illustrated in Nakrem (2002). Hederella carbonaria also described from the lower Permian (Sakmarian) of Russia (Lisitsyn 1998) was considered a candidate for the youngest occurrence of the Order Hederelloidea, but this is disputed since there exist other tentative records (Taylor \& Wilson 2008). In this work, we describe Hederella carbonaria Condra \& Elias 1944 from the lower-middle Permian of Paso Hondo Formation, Chiapas, Mexico; this is the first report of hederelloids from Mexico and extends its stratigraphic range up into the Roadian.

\section{Geological Setting}

The Paso Hondo Formation is the youngest Permian lithostratigraphic unit in the Chicomuselo area, and it extends from the western portion of Paso Hondo to the town of Chicomuselo (Thompson 1956) (Fig. 1). The Late Paleozoic succession in the Chiapas area is represented by the carbonate deposits of the Santa Rosa

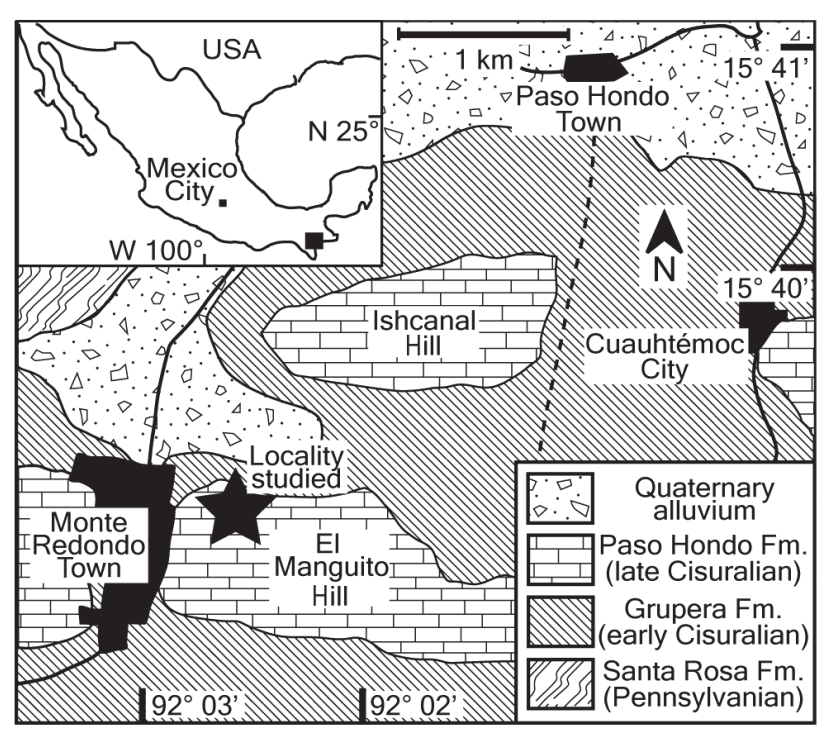

Figure 1. Map of Mexico and geological map of the locality studied (modified from Weber et al. 2007).
Formation (Mississippian-Pennsylvanian), Grupera Formation (Asselian-Sakmarian), La Vainilla Limestone (Sakmarian-Artinskian), and the youngest Paso Hondo Formation (Artinskian-Roadian) studied herein.

The Paso Hondo Formation overlays the La Vainilla Limestone transitionally and is composed of approximately $600 \mathrm{~m}$ of rarely stratified massive limestone, with intercalations of silicified shale near its base (GutiérrezGil 1956). Facies of this unit record different associations of fusulinids, sponges, corals, bivalves, gastropods, bryozoans, brachiopods and crinoids from the ArtinskianRoadian. Overlying unconformably to the Paso Hondo Formation is the Todos Santos Formation, composed by a group of red sandstone strata intercalated with fine layers of shale dated as Triassic-Jurassic (Gutiérrez-Gil 1956).

\section{Systematic Paleontology}

The material described herein is housed at the Colección Nacional de Paleontología of the Instituto de Geología, Universidad Nacional Autónoma de México. Figured specimens are designated in the descriptions by the prefix IGM.

Suborder Hederelloidea Bassler, 1939

Family Hederellidae Kiepura, 1973

\section{Genus Hederella Hall, 1881}

Type species. - Alecto canadensis Nicholson 1873.

Diagnosis. - "Hederellid with adnate zoaria, forming pluriserial expansions, with autozooecia budded laterally from stolozooecia" (Bancroft 1986).

Occurrence. - Mid-Silurian to middle Permian (Roadian).

\section{Hederella carbonaria Condra \& Elias, 1944}

Figures 2A, B; 3A, B; 4A-D

1932 ?Hederella n. sp; Girty in Gilluly, p. 33.

1944 Hederella carbonaria. - Condra \& Elias, p. 536, pl. 89 , figs $1-5$, pl. 90 , figs $1,2$.

1944 Hederella cf. chesterensis. - Dunham \& Stubblefield, p. 256, pl. 11, fig. 1 .

1986 Hederella carbonaria Condra \& Elias, 1944. - Bancroft, p. 244, text-figs 2,3 .

1998 Hederella carbonaria Condra \& Elias, 1944. - Lisitsyn, p. 590 , text-fig. 1 .

Types. - Syntypes: US Geological Survey nos 451, 453-A, and 453-B. The section along Highway no. 75 two miles 
Figure 2. A - Hederella carbonaria from Paso Hondo Formation (IGM 9521); B - sketch of Hederella carbonaria indicating the autozooecia (a) and the stolozooecium (s).
Figure 3. A - Hederella carbonaria (arrows) on dorsal valve of a rhynchonellid brachiopod (IGM 9521); B - Hederella carbonaria (IGM 9522) (arrows) on a ventral valve of an athyridid brachiopod.
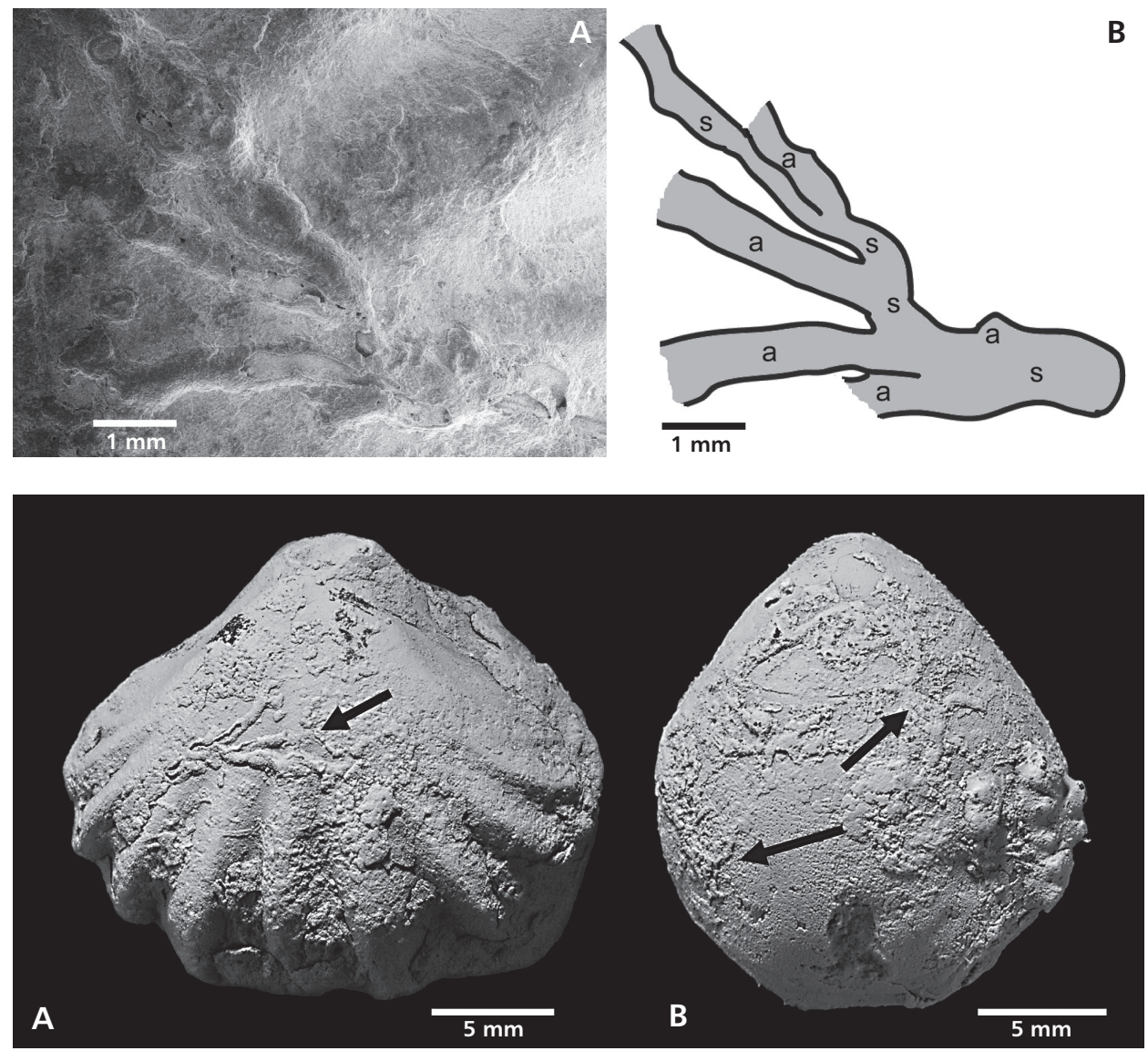

south of Bartlesville, Oklahoma, the USA; middle Pennsylvanian, Missourian, the base of the Dewey Limestone.

Material. - Three colonies: one incrusted on rhynchonellid brachiopod (IGM 9521) and two colonies on athyridid brachiopods (IGM 9522, IGM 9523).

Description. - Adnate colonies, not fully preserved, irregularly pluriserial with dichotomizing branches, all colonies are incrusted on brachiopods shells. Stolozooecia are long and slightly sinuous, circular to oval cross section. Cylindrical autozooecia are budded from stolozooecium, generally they are constant in diameter, and some autozooecia are funnel-like. Autozooecia have a circular to elliptical cross section. They are straight or gently curved. The autozooecia diverge from stolozooecia at low angles about $20^{\circ}$ to $70^{\circ}$ in closely spaced intervals, some are in contact with neighboring zooecia for a part or their entire length. Proximal parts of autozooecia are connected with the stolozooecium but a few apparently not. Uncommon autozooecia are budded from the frontal surface of stolozooecia. In the distal part of zooecia, the apertures are elliptic. Zooecia are annulated in a rippled transverse appearance. Internally the zooecia form continuous interconnected tubes. The skeletal ultra- structure is possibly microprismatic but it is not well preserved. Measurements are summarized in Table 1.

Remarks. - Hederella carbonaria from Paso Hondo Formation is similar in morphology and size to specimens described by Condra \& Elias (1944) from the upper Carboniferous of Utah and Oklahoma, and those described by Bancroft (1986) from the lower Carboniferous of Great Britain. The specimens reported by Lisitsyn (1998) only exhibit internal characteristics, so a broader comparison is difficult. The skeletal ultrastructure has not been described in previous works.

Occurrence. - Lower Carboniferous, upper Viséan of Great Britain; upper Carboniferous, lower and middle Pennsylvanian, Missourian, (Oklahoma and Utah) North America; lower Permian, Sakmarian of the Central Urals; middle Permian, Roadian of Chiapas, Mexico.

\section{Discussion}

The Paso Hondo Formation is the youngest Permian lithostratigraphic unit from the Chicomuselo region. The age of this unit was established on account of the presence 
Table 1. Measurements of the species Hederella carbonaria Condra \& Elias, 1944 from the Paso Hondo Formation. Abbreviations: NM - number of measurements; $\mathrm{X}$ - mean; $\mathrm{SD}$ - standard deviation; $\mathrm{CV}$ - coefficient of variation; $\mathrm{MIN}$ - minimal value; $\mathrm{MAX}-$ maximal value. ( $\mathrm{N}=3$ ).

\begin{tabular}{|c|c|c|c|c|c|c|}
\hline & NM & $\mathrm{MIN}$ & MAX & $\mathrm{X}$ & $\mathrm{SD}$ & $\mathrm{CV}$ \\
\hline Autozooecial length, mm & 17 & 1.30 & 3.00 & 1.65 & 0.44 & 26.68 \\
\hline Autozooecial chamber diameter, mm & 18 & 0.30 & 0.50 & 0.40 & 0.06 & 14.82 \\
\hline Autozooecial aperture diameter, mm & 10 & 0.16 & 0.35 & 0.23 & 0.05 & 24.25 \\
\hline Thickness of zooecial walls, mm & 8 & 0.04 & 0.10 & 0.06 & 0.02 & 33.10 \\
\hline Stolozooecia chamber diameter, $\mathrm{mm}$ & 9 & 0.25 & 0.60 & 0.41 & 0.11 & 26.28 \\
\hline
\end{tabular}
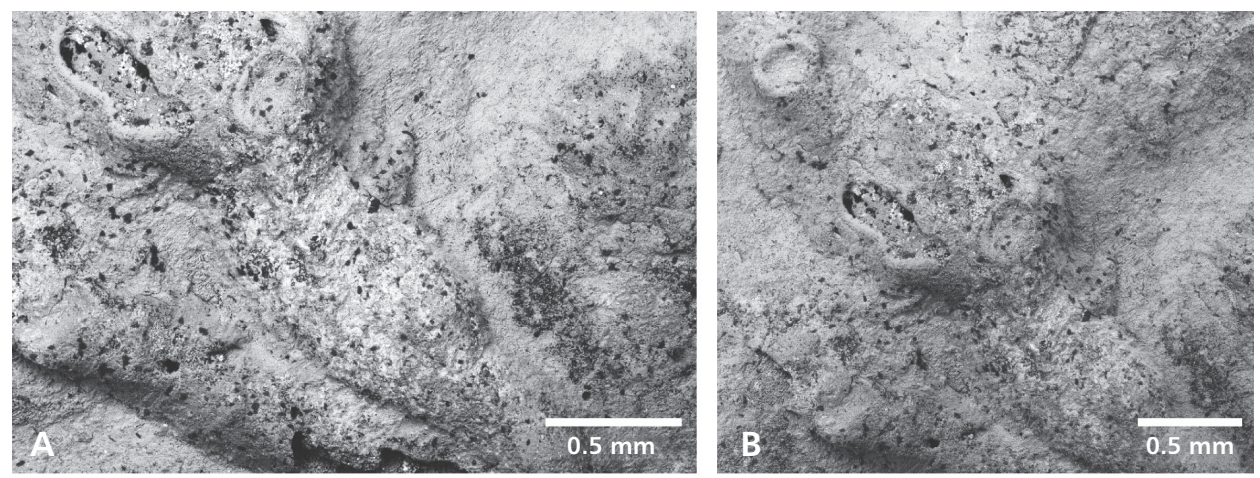

Figure 4. Hederella carbonaria from Paso Hondo Formation, Chiapas, Mexico; A - budding autozooid from stolozooecium (IGM 9521); B - stolozooecium and autozooecium apertures (IGM 9521); C - elliptical aperture of autozooid (IGM 9521); D - the possibly microprismatic skeletal ultrastructure (specimen IGM 9522) is not well preserved.
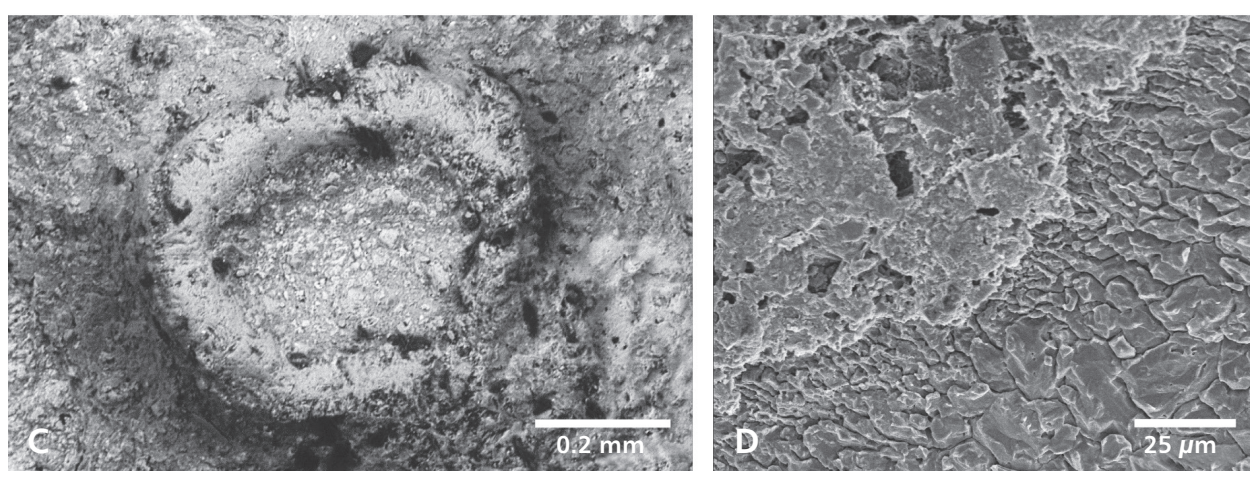

of biostratigraphically diagnostic foraminifera, such as Parafusulina australis, Schubertella mullerriedi, Staffella centralis and Eoverbeekina americana (Thompson \& Miller 1944), as well as the ammonoid Perrinites hilli (Mullerried et al. 1941). These taxa were correlated with faunas of coeval units in the Leonard Formation of Texas and the Chochal Formation of Guatemala, indicating an Artinskian-Kungurian age (late Cisuralian). Nevertheless, the Chochal Formation contains not only strata of the late Cisuralian, but also strata from the early Guadalupian (Vachard et al. 1997). In this context, at the locality studied, we found typical brachiopods from the early-middle Permian, such Dyoros (Tetragonetes) rectangulatus (Roadian-Wordian), Costispinifera rugatula (Roadian-Wordian), Tropidelasma furcillatum (Roadian), Composita enormis (Roadian-Wordian), Composita hapsida (Kungurian), Tautosia transenna
(Roadian-Wordian) and Wellerella lemasi (Wordian), and found Hederella associated with the last three (TorresMartínez et al. 2018). These species suggest that the strata of the studied area have a Kungurian-Roadian age, similar to the Chixoy section (Chochal Formation) of Guatemala (Vachard et al. 1997). This is significant as it provides the first report globally of Hederella carbonaria for the late Cisuralian-early Guadalupian.

\section{Conclusions}

The presence of hederelloids in the Paso Hondo Formation, State of Chiapas, constitutes the first record of this group for Mexico, the youngest at a global level, and extends the temporal distribution of the Order Hederelloidea to the Roadian. 


\section{Acknowledgments}

We are grateful to H.A. Nakrem and A. Ernst by their valuable comments and suggestions. The authors thank for photographic work to E.P. Porras-López, B. Mendoza-Garfias (SEM images) of Laboratorio de Microscopía y Fotografía de la Biodiversidad I (LANABIO) and A.M. Reyes-Salas (SEM images) of Instituto de Geología, UNAM. This work was supported by the Dirección General de Asuntos del Personal Académico (DGAPA) UNAM through project PAPIIT IA102618. The first author acknowledges Posgrado en Ciencias Biológicas, UNAM and CONACYT for his graduate fellowship (No. 330554).

\section{References}

Bancroft, A.J. 1986. Hederella carbonaria Condra and Elias, a rare ?bryozoan from the Carboniferous of Great Britain. Proceedings of the Geologists' Association 97(3), 243-248. DOI 10.1016/S0016-7878(86)80018-9

Bassler, R.S. 1939. The Hederelloidea: A Suborder of Paleozoic Cyclostomatous Bryozoa. Proceedings of the United States National Museum 87, 25-91. DOI 10.5479/si.00963801.87-3068.25

Brood, K. 1973. Palaezoic Cyclostomata (A preliminary report), 247-256. In LARwood, G.P. (ed.) Living and Fossil Bryozoa. Academic Press, London.

Brood, K. 1975. Cyclostomatous Bryozoa from the Silurian of Gotland. Stockholm Contributions in Geology 28, 45-119.

Condra, G.E. \& Elias, M.K. 1944. Hederella and Corynotrypa from the Pennsylvanian. Journal of Paleontology 18(6), 535-539.

Dunham, K.C. \& Stubblefield, C.J. 1944. The stratigraphy, structure and mineralization of the Greenhow mining area, Yorkshire. Quarterly Journal of the Geological Society 100(1-4), 209-268.

DOI 10.1144/GSL.JGS.1944.100.01-04.15

DzIK, J. 1981. Evolutionary relationships of the Early Palaeozoic "Cyclostomatous" Bryozoa. Palaeontology 24(4), 827-861.

Gilluly, J. 1932. Geology and ore deposits of the Stockton and Fairfield quadrangles, Utah. U.S. Geological Survey Professional Paper 173, 1-165.

Gutiérrez-Gil, R. 1956. Bosquejo geológico del estado de Chiapas, 9-32. In Maldonado-Koerdell, M. (ed.) Geología del Mesozoico y estratigrafia pérmica del Estado de Chiapas, Excursión C-15, XX Congreso Geológico Internacional.

HaLl, J. 1881. Bryozoans of the Upper Helderberg and Hamilton Groups. Transactions of the Albany Institute 10, 145-197.

Kiepura, M. 1973. Devonian bryozoans of the Holy Cross Mountains, Poland. Part II. Cyclostomata and Cystoporata. Acta Palaeontologica Polonica 18(4), 325-400.

Lisitsyn, D.V. 1998. The First Permian Find of the Genus Hederella (Bryozoa). Paleontological Journal 32(6), 589-591.
Mullerried, F.K.G., Miller, A.K. \& Furnish, W.M. 1941. The middle Permian of Chiapas, southernmost Mexico, and its fauna. American Journal of Science 239(6), 397-405. DOI 10.2475/ajs.239.6.397

NAKRem, H.A. 2002. A Moscovian (Carboniferous) bryozoan buildup from Svalbard, 239-245. In WySE JACKSON, P.N., Buttler, C. \& Spencer Jones, M. (eds) Bryozoan Studies 2001. Swets \& Zeitlinger, Lisse.

Nicholson, H.A. 1873. Descriptions of new fossils from the Devonian rocks of Western Ontario. Canadian Naturalist, new series 7, 138-147.

SCHNEIDER, C.L. 2008. Substrate preferences of Middle and Late Devonian Hederella from the Midcontinent USA, 281-294. In Hageman, S.J., Key, M.M. JR. \& Winston, J.E. (eds) Bryozoan Studies 2007: proceedings of the 14th international bryozoology conference, Boone, North Carolina, July 1-8. Virginia Museum of Natural History Special Publication 15.

SCHNEIDER, C.L. 2013. Epibiosis across the Late Devonian biotic crisis: a review. Proceedings of the Geologists' Association 124, 893-909. DOI 10.1016/j.pgeola.2013.05.002

SolLE, G. 1952. Neue Untergattungen und Arten der BryozoenGattung Hederella und eine Hernodia im rheinischen Unterdevon. Notizblatt des Hessischen Landesamtes für Bodenforschung zu Wiesbaden 6(3), 35-55.

Taylor, P.D. \& Wilson, M.A. 2003. Palaeoecology and evolution of marine hard substrate communities. EarthScience Reviews 62(1-2), 1-103.

TAYLOR, P.D. \& WiLsOn, M.A. 2008. Morphology and affinities of hederelloid "bryozoans", 301-309. In Hageman, S.J., Key, M.M. JR. \& Winston, J.E. (eds) Bryozoan Studies 2007: proceedings of the $14^{\text {th }}$ international bryozoology conference, Boone, North Carolina, July 1-8. Virginia Museum of Natural History Special Publication 15.

DOI 10.1016/S0012-8252(02)00131-9

Thompson, M.L. 1956. Rocas paleozoicas del sur de México, 61-68. In Maldonado-Koerdell, M. (ed.) Geología del Mesozoico y estratigrafía pérmica del Estado de Chiapas, Excursión C-15, XX Congreso Geológico Internacional.

Thompson, M.L. \& Miller, A.K. 1944. The Permian of southernmost Mexico and its fusulinid faunas. Journal of Paleontology 18, 481-504.

Torres-Martínez, M.A., Heredia-Jiménez, D.P., Sour-Tovar, F., Buitrón-SÁnchez, B.E. \& Barragán, R. 2018. Permian brachiopods from Chiapas, Mexico: new stratigraphical and paleobiogeographical insights. Paläontologische Zeitschrift. DOI 10.1007/s12542-018-0436-2

Vachard, D., Fourcade, E., Romero, J.E., Mendez, J., Cosillo, A., Alonzo, M., Requena, J., Azema, J. \& Cros, P. 1997. Foraminifères et algues du Permien du Guatemala. Geobios 30(6), 745-784. DOI 10.1016/S0016-6995(97)80177-5

Weber, B., Iriondo, A., Premo, W.R., Hecht, L. \& Schaf, P. 2007. New insights into the history and origin of the southern Maya block, SE México: U-Pb-SHRIMP zircon geochronology from metamorphic rocks of the Chiapas massif. International Journal of Earth Sciences 96(2), 